\title{
Is pain perception different in pediatric and adult patients undergoing stone crushing procedure after the application of multimodal analgesia?
}

\author{
Özbay Engin ${ }^{1}$ Erdem Erim ${ }^{2}$ \\ ${ }^{1}$ Department of Urology, Istanbul Kanuni Sultan Süleyman Research and Training Hospital, İstanbul, Turkey \\ ${ }^{2}$ Department of Urology, Mersin Univercity Medicine School, Mersin, Turkey
}

Received: 2021-06-26.

Accepted: 2021-08-13

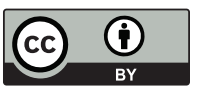

This work is licensed under a Creative Commons Attribution 4.0 International License

J Clin Med Kaz 2021; 18(5):59-62

Corresponding author:

Özbay Engin.

E-mail: enozbay63@gmail.com

ORCID: 0000-0001-7102-3064

\begin{abstract}
Aim: Extracorporeal shock wave lithotripsy (ESWL) is an important modality in the treatment of urinary system stone disease in children and adults. However, ESWL may be painful and stressful procedure. We aimed to examine the differences between pain perception felt during ESWL in pediatric and adult patients after the application of multimodal analgesia.

Material and methods: Patients who underwent the stone crushing procedure under multimodal analgesia at the ESWL unit of Mersin University Hospital Urology Clinic between May 2010 and December 2010, were divided into two groups as pediatric and adult. Using the VAS (Visual Analog Scale) form, the adult patients' and pediatric patients' pain perception felt during ESWL, were scored and compared.

Results: The success rate for ESWL was calculated as $83.3 \%$ for the pediatric group and $80 \%$ for the adult group. The first, second and third ESWL sessions mean VAS scores were $4.54 \pm 1.13,4.55 \pm 1.11,4.53 \pm 1.14$ for pediatric group and $3.58 \pm 1.18,3.56 \pm 1.20,3.57 \pm 1.19$ for the adult group. There was no statistically significant difference between the 1st ESWL session, 2nd ESWL session and 3rd ESWL session mean VAS scores in the pediatric group or adult group ( $p>0.05$ ). But the 1st ESWL session, 2nd ESWL session and 3rd ESWL session mean VAS scores of the pediatric group were found to be statistically significantly higher than the adult group $(p<0.05)$.

Conclusion: ESWL is a painful procedure. Our ESWL success rate is compatible with the literature. The pediatric and adult patients successfully completed the ESWL procedure with multimodal analgesia. ESWL sessions have no effect on each other for the pain perception felt during ESWL but the pain perception felt during ESWL score was higher in pediatric cases.
\end{abstract}

Key words: extracorporeal shock wave lithotripsy, pain perception, Visual Analog Scale, multimodal analgesia

\section{Introduction}

The incidence of renal stone disease varies between $1-20 \%$, and countries where it reaches up to $37 \%$ are followed $[1,2]$. Pediatric stone disease accounts for $2-3 \%$ of all stone disease cases and it is most common in children of both sexes, equally between the ages of 5 and 7 years [3].

Symptoms of renal stone-related flank pain, abdominal pain, urinary infection and hematuria can be seen. If the treatment of renal stone is not performed at the appropriate time, secondary diseases due to pain, urosepsis, renal dysfunction and end-stage renal failure may also be observed [4]. Medical and interventional treatment procedures are available for the treatment of renal stone disease. ESWL is highly preferred in the interventional treatment procedure [4].

Extracorporeal shock wave lithotripsy (ESWL), which has been successfully applied for many years, is an important modality in the treatment of pediatric and adult urinary system stone disease [5]. Compared to minimally invasive and invasive methods, ESWL has many advantages in the treatment of kidney stones, such as fast recovery, less side effects, low kidney injury rate, and ease of re-treatment [6].

During the ESWL procedure, as a subjective feeling that is difficult to define, pain is sometimes described by patients with an intensity that may require general 
anesthesia in addition to the application of analgesic and sedoanalgesic agents [7]. It is known that anxiety before ESWL increases and continues during the procedure has an effect on this pain. In order for the stone to crush easily during ESWL, the fact that the patient is cooperated and does not feel pain is important in increasing the effectiveness of ESWL [7].

The pain related to ESWL is complex acute pain. Multimodal analgesia is recommended in complex acute pain management. Pharmacological agents, regional anesthesia, rehabilitation, cognitive behavioral therapy, increasing morale, and non-pharmacological methods are recommended for this treatment $[8,9]$. Failure to prevent or minimize treatable procedural pain in children is now considered both inappropriate and unethical [10]. Visual Analog Scale (VAS) has been widely used in studies to evaluate acute pain severity. The VAS form has proven itself for a long time and is a test that has been accepted in the world literature. It is safe, easy to apply [11].

In our retrospective study, we aimed to evaluate the pain perception felt during ESWL with recording VAS scores in children and adult patients after the application of multimodal analgesia and also to compare the both group's pain perception felt during ESWL.

\section{Material and methods}

Child and adult patients who applied to Mersin University Hospital Urology Clinic, were diagnosed with urinary system stone disease as a result of the tests and underwent ESWL for one to three sessions with ten days intervals were included in the study. All patients had symptoms related to an average of 1-2 $\mathrm{cm}$ renal stones without urinary infection. All the stones were radio-opaque. The patients were divided into two groups as pediatric (n: 18) and adult (n: 20). ESWL was applied to 38 renal units. After a physical examination and before ESWL, urine analysis and urine culture, serum urea, creatinine and electrolyte level, complete blood count, prothrombin (PTT) and aPTT level measurements were undertaken in all patients. ESWL was performed after successful antibiotic therapy in the patients that were found to have a urinary infection. ESWL contraindications (pregnancy, bleeding diathesis, severe skeletal system malformation, and obesity that would not allow the procedure) were also used as exclusion criteria. Previous ESWL treatment and psychiatric illness diseases were also an exclusion criteria.

Application of multimodal analgesia and ESWL: 40 minutes before the procedure intramuscular diclofenac sodium (0,5-2 $\mathrm{mg} / \mathrm{kg}$ for pediatric patient) was administered to patients, and then the assistant physician responsible for the ESWL unit had told how to perform the procedure with the device to the patient and the procedure was followed at the time of another patient's treatment. A Multimed classic device (Elmed, 2010, Turkey) was used for ESWL. For the procedure, the pediatric patients received an average of 1,700 waves $(1,500-2,000)$ and a maximum of $15 \mathrm{Kv}$ while the adults were applied 2,300 waves $(1,500-2,500)$ and a maximum of $18 \mathrm{Kv}$. The processing time was 40 minutes. At the 20th minute of the procedure, the VAS score that the patient felt was written by the assistant physician. There is a $10 \mathrm{~cm}$ ruler in the VAS form with painlessness on one end and the most severe pain on the other. The place marked by the patient on the ruler indicates his/her own pain. It is a onedimensional method of measuring pain [8]. After the procedure, the patients were kept under observation for two hours.

At the end of the first week, the patients were evaluated with urinalysis, direct urinary tract radiography, and urinary ultrasonography. In cases where the stones were not fragmented, or fragmentation was not sufficient, the patients were called for a further ESWL session.

The mean VAS scores of the first, second and third ESWL sessions were calculated for the pediatric and adult groups. The mean VAS scores of the same ESWL sessions of both groups were compared, and the mean VAS scores of each group due to three different ESWL sessions were compared within their own groups. By analyzing VAS scores related to ESWL sessions, we aimed to examine the differences between pain perception felt during ESWL in pediatric and adult patients after the application of multimodal analgesia.

IBM SPSS Statistics 22.0 program was used for statistical analysis. While evaluating the study data, in addition to descriptive statistical methods (Mean, Standard deviation), Friedman's S test was used for the analysis of variance between repeated measurements of quantitative data that did not show normal distribution, and Wilcoxon Signed Ranks test was used for the analysis of the difference between repetitions. Significance was evaluated at the $\mathrm{p}<0.05$ level.

\section{Results}

Pediatric group included 10 boys and eight girls, with a mean age of $12.94 \pm 2.63$ years and adult group included 14 males and six females, with a mean age of $46 \pm 9.25$ years. Body mass index (BMI) was $25.68 \pm 4.63$ in the adult group and it was $23.34 \pm 27$ in the pediatric group. In the pediatric group, eighteen patients completed first ESWL session, ten patients completed second ESWL sessions and four patients completed third ESWL session. In the adult group, twenty patients completed first ESWL session, fourteen patients completed second ESWL sessions and six patients completed third ESWL session. The success rate was calculated as $83.3 \%$ for the pediatric group and $80 \%$ for the adult group.

Table 1 presents the comparison of the VAS Scores related to ESWL Sessions between and within the Pediatric Group and Adult Group.

\section{Table 1}

Comparison of the VAS Scores related to ESWL Sessions between and within the Pediatric Group and Adult Group

\begin{tabular}{|l|l|l|l|}
\hline VAS Score & $\begin{array}{l}\text { Pediatric } \\
\text { Group }\end{array}$ & Adult Group & $1 \mathrm{p}$ \\
\hline & Mean \pm SD & Mean \pm SD & \\
\hline 1st ESWL & $4.54 \pm 1.13$ & $3.58 \pm 1.18$ & $0.001^{* *}$ \\
\hline 2nd ESWL & $4.55 \pm 1.11$ & $3.56 \pm 1.20$ & $0.001^{* *}$ \\
\hline 3hd ESWL & $4.53 \pm 1.14$ & $3.57 \pm 1.19$ & $0.001^{* *}$ \\
\hline 2p & 1.000 & 1.000 & \\
\hline 3p 1st ESWL- 2nd ESWL & 1.000 & 1.000 & \\
\hline 3p 1st ESWL- 3hd ESWL & 1.000 & 1.000 & \\
\hline 3p 2nd ESWL-3hd ESWL & 1.000 & 1.000 & \\
\hline
\end{tabular}

For comparison of the same ESWL session's mean VAS score between the groups: The first ESWL session mean VAS score of the pediatric group was found to be statistically significantly higher than the adult group $(p<0.05)$. The second ESWL session mean VAS score of the pediatric group was found to be statistically significantly higher than the adult group $(p<0.05)$. The third ESWL session mean VAS score of the pediatric group was found to be statistically significantly higher than the adult group $(\mathrm{p}<0.05)$. 
Figure 1 - The chart of the mean VAS scores of the pediatric and adult patient groups.

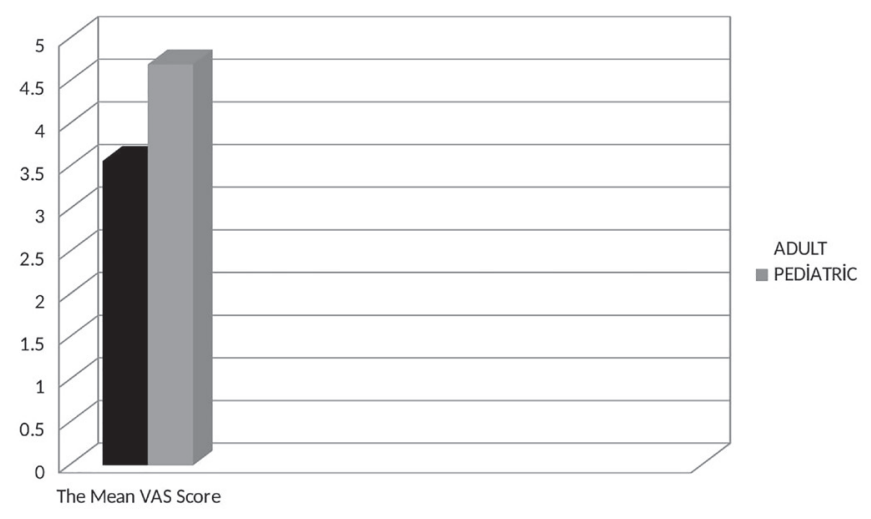

For comparison of the different ESWL sessions' mean VAS scores within the same group: In the pediatric group; There was no statistically significant difference between the mean VAS 1st ESWL session, 2nd ESWL session and 3rd ESWL session scores $(p>0.05)$. In the adult group; There was no statistically significant difference between the mean VAS 1st ESWL session, 2nd ESWL session and 3rd ESWL session scores ( $p>0.05)$.

\section{Discussion}

In children, ESWL has high efficiency and reliability with a high success rate [12]. It is also applied with a high success rate in adult patients [13]. While the success rate is affected by stone size, density and localization in pediatric patients, in adult cases, in addition to these factors, body mass index and skinstone distance are also effective [12,14]. In our retrospective study, the success rate of ESWL for $1-2 \mathrm{~cm}$ sizes radio-opaque renal stones without in pediatric and adult groups were followed in accordance with the literature and also no abnormality were observed in the BMI ratios of both groups.

In health interventions, exposure to severe pain without adequate pain management may lead to long-term negative consequences, such as morbidity and mortality, as well as fear and avoidance of future medical procedures [15]. Therefore, adequate pain management is essential for pediatric patients aged 0 to 17 years [16]. Different methods of analgesia, especially sedo-analgesia, have been applied in pediatric patients during ESWL in order to reduce the morbidity related to the procedure and ensure patient compliance. Fentanyl or midazolam is used for sedation and ketamine for analgesia [17]. General anesthesia may also be required for pediatric cases with pain intolerance. ESWL has been successfully performed with intramuscular analgesics (diclofenac sodium) in children over 12 years of age [18]. In a study by Gönener et al. [19], it was observed that giving descriptive and introductory information about the procedure to school children increased their pain threshold and decreased their fear in relation to the procedure. In our study the mean age of pediatric patients was 12.98 . The patients completed the ESWL procedure after the application of multimodal analgesia (descriptive and introductory information + intramuscular diclofenac sodium). There was no need for sedo-analgesia or general anesthesia in any of the cases.

Some studies showed that informing adult patients undergoing ESWL about the procedure played an important role in reducing their pain score, as well as increasing their level of understanding about the process $[20,21]$. Thus, the anxiety intensity of adult patients decreases $[22,23]$. There are also studies investigating the primary preference of non-steroid anti- inflammatory drugs (NSAIDs) during ESWL. In a meta-analysis comparing NSAIDs and opioids, the two groups of drugs were observed to equally relieve pain during ESWL [24]. In another study conducted by Özkan et al., it was reported that lornoxicam (an NSAID) administered before ESWL had a better analgesic effect than paracetamol and tramadol [25]. In addition, in a study on renal colic pain treatment, NSAIDs were concluded to be stronger analgesics with fewer side effects compared to opioids [26]. In our study, the adult patients completed the ESWL procedure after the application of multimodal analgesia (descriptive and introductory information + intramuscular diclofenac sodium).

The VAS form is accepted as a safe, valid and usable measurement tool for repeated measurements. There was no significant difference in the responses given after the test's short intervals and repetitions [27]. In studies conducted for the treatment of experienced pain due to ESWL, no significant difference was detected in the VAS scores measured more than once $[20,22]$. . De Sio et al evaluated the pain tolerability in ESWL sessions with a relatively newer machine, and nearly half of the cases scored their pain on a VAS as 4 or 5 [28]. In our study, since the desired scores were answered with in a certain short period of time, we received only one answer in the tests we repeated. The first, second and third ESWL sessions mean VAS scores were $4.54 \pm 1.13,4.55 \pm 1.11,4.53 \pm 1.14$ for pediatric group and $3.58 \pm 1.18,3.56 \pm 1.20,3.57 \pm 1.19$ for the adult group. There was no statistically significant difference between the 1st ESWL session, 2nd ESWL session and 3rd ESWL session mean VAS scores in the pediatric group or adult group $(\mathrm{p}>0.05)$.

The child is physiologically and cognitively immature, but a developing creature, not a miniature of the adult. The physical, cognitive and emotional reactions to the disease vary according to the developmental period, and everything that affects the family as a system also affects the child [29]. Anatomical differences, physiological differences and behavior patterns towards the disease between children and adults affect an important role in the pain perception [30]. Hasanpoura found that pain perception decreased with increasing age in his research with children aged 5-12 years [31]. In another study, they argued that pain perception decreased as a result of the development of pain control methods with increasing age $[32,33]$. In our study all the same ESWL sessions mean VAS scores of the pediatric group were found to be statistically significantly higher than the adult group $(\mathrm{p}<0.05)$.

\section{Conclusion}

ESWL is a painful procedure. In our study, Our ESWL success rate is compatible with the literature. Pediatric and adult patients successfully completed the ESWL procedure with multimodal analgesia. ESWL sessions have no effect on each other for the pain perception felt during ESWL but the pain perception felt during ESWL was higher in the pediatric group.

\section{Ethics committee approval}

All procedures performed in studies involving human participants were in accordance with the ethical standards of the institutional and/ or national research committee and with the 1964 Helsinki Declaration and its later amendments or comparable ethical standards.

Disclosures: There is no conflict of interest for all authors. Acknowledgements: None.

Funding: None. 


\section{References}

1. Trinchieri A. et al. Epidemiology, in Stone Disease, K.S. C.P. Segura JW, Pak CY, Preminger GM, Tolley D., Editors. 2003, Health Publications: Paris.http://www.icud.info/PDFs/Stone-Disease.pdf

2. Incidence and prevalence of published studies about urolithiasis in Spain. A review [Spanish]. Actas Urol Esp. 2007; 31(5):511-20. https://doi.org/10.1016/s0210-4806(07)73675-6

3. Bal A, Şahudak Bal Z, Alparslan C, et al. Çocukluk çağı üriner sistem taş hastalığında etiyolojik faktörler ve tedavi. Türkiye Klinikleri J Med Sci. 2013; 33(4):1127. http://dx.doi.org/10.5336/medsci.2012-32741

4. Çocuklarda üriner sistem taş hastalığı. Çocuk Cerrahisi Dergisi. 2013; 27(1):8-32. http://doi:10.5222/JTAPS.2013.008

5. Menon M, Resnick MI. Urinarylithiasis: etiology, diagnosis and medical management. In: Walsh, Retik AB, Vaughan AB (eds). Campbell's Urology 8'th edition. Philadelphia: WB Saunders Company 2002: 3289-92. https://www.worldcat.org/title/campbell-walshurology/oclc/541668190

6. Choong S, Whitfield H, Duffy P, et al. The management of pediatric urolithiasis. Journal of Urology. 2002; 168:1522-25. https://doi. org/10.1046/j.1464-410x.2000.00909.x

7. Gupta NP, Kumar A. Analgesia for pain control during extracorporeal shockwave lithotripsy. İndian J Urol. 2008; 24:155-158. https:// doi.org/10.4103/0970-1591.40607

8. Downie WW, Leatham PA. Studies with pain ratings cales. Annals Rheumatic Diseases. 1978; 37:378-381. https://doi.org/10.1136/ $\operatorname{ard} .37 .4 .378$

9. Friedrichsdorf SJ, Goubert L. Pediatric pain treatment and prevention for hospitalized children. Pain Rep. 2019; 5(1):e804. https://doi. org/10.1097/pr9.0000000000000804

10. Friedrichsdorf SJ, Sidman J, Krane EJ. Prevention and treatment of painin children: toward a paradigm shift. Otolaryngol Head Neck Surg. 2016; 154:804-5.1 https://doi.org/10.1177/0194599816636100

11. Goubert L, Friedrichsdorf SJ. https://www.childresmn.org/painpallativeintegrativemed 2019.

12. Sultan S. Urolithiasis. In: Lima M, Manzoni G, editors. Pediatric Urology: Contemporary StrategiesFromFetal Life to Adolescence. Milan: Springer. 2015; 365-78. https://doi.org/10.1007/978-88-470-5693-0_30

13. Sohail N, Albodour A, Abdelrahman KM.Is There Any Improvement In Efficacy Of Extracorporeal Shockwave Lithotripsy Therapy For Treating Renal Stones With Invent Of New Shockwave Machines? J Ayub Med Coll Abbottabad. 2019; 31(3):351-354.

14. Pareek G, Armenakas NA, Panagopoulos G, Bruno JJ, Fracchina JA. Extracorporeal shockwave lithotripsy success based on body mass index and Hounsfield units. Urology. 2005; 65:33-36. https://doi.org/10.1016/j.urology.2004.08.004

15. Ozkan F, Erdemir F, Erkorkmaz U, et al. Comparision of three different analgesic protocols during shockwave lithotripsy. J Endourol. 2012; 26:691-696. https://doi.org/10.1089/end.2011.0004

16. Bach C, Zaman F, Kachrilas S, Kumar P, Buchholz N, Masood J. Drugs for pain management in shock wave lithot- ripsy. Pain Res Treat. 2011; 2011:259426. https://doi.org/10.1155/2011/259426

17. Berwin JT, El-Husseiny T, Papatsoris AG, Hajdinjak T, Masood J, Buchholz N. Pain in extracorporeal shock wave lithotripsy. Urol Res. 2009; 37:51-3. https://doi.org/10.1007/s00240-009-0171-y

18. Anand KJ, Barton BA, McIntosh N, et al. Analgesia and sedation in preterm neonates who require ventilatory support: results from the NOPAIN trial. Neonatal outcome and prolonged analgesia. Neonates Architure Pediatr Adolescent Medicine. 1999; 153(4):331-338. https://doi.org/10.1001/archpedi.153.4.331

19. Brattberg G. Do pain problems in young school children persistin to early adulthood. A 13 yearfollowup. European Journal of Pain. 2004; 8(3):187-199. https://doi.org/10.1016/j.ejpain.2003.08.001

20. Cevik B, Tuncer M, Sarıca K. Procedural sedation and analgesia for pediatric shockwave lithotripsy: a 10 year experience of single instution. Urolithiasis. 2018; 46(4):363-367. https://doi.org/10.1007/s00240-017-0992-z

21. Özçakır E, Özçakır L, Kaçar M, ve ark. Çocuklarda üriner sistem taş hastalı̆̆ı tedavisinde ESWL deneyimlerimiz. Çocuk Cerrahisi Dergisi. 2010; 24(1):12-7. https://www.journalagent.com/cocukcerrahisi/pdfs/CCD_24_1_12_17.pdf

22. Günerer D,Gürek G. Okul yaş grubu çocukların hastane ve hastalığı ile ilgili bilgilendirme durumlarının endişe kaynakları ile etkileşimi. Gaziantep Tip Dergisi. 2008; 15(1):41-48. https://dergipark.org.tr/tr/pub/deuhfed/issue/53195/705950

23. Bovelander E, Weltings S, Rad M, et al. The influence of pain on the outcome of extracorperal shockwave lithotripsy. Curr Urol. 2018; 12:81-7. https://doi.org/10.1159/000489424

24. TokgözH, Hanci V, Turksoy O, et al. Pain perception during shockwave lithotripsy: does it corrolate with patient and Stone characteristics? J ChinMedAssoc. 2010; 73:477-482. https://doi.org/10.1016/s1726-4901(10)70102-7

25. Yılmaz E, Batıislam E, Tuğlu D, ve ark. Ekstrakorporeal shockwave litotripsi sırasında hastalarda anksiyete-ağrı yoğunluğu ilişkisi. Türk Üroloji Dergisi. 2003; 29(1):80-83. https://app.trdizin.gov.tr/publication/paper/detail/TWpJM016SXk=

26. SalinasA, Lorenzo-Romero T, Segura M, et al. Factors determining analgesic and sedative drug requirements during extracorporeal shockwave lithotripsy. Urology İnternational. 1999; 63:92-101. https://doi.org/10.1159/000030425

27. Mezentsev VA. Meta analysis of the efficacy of non-steroidal anti-inflamatory drugs vs. opoids for SWL using modem electromagnetic litotripters. İnt braz j urol. 2009; 35:293-298. https://doi.org/10.1590/s1677-55382009000300005

28. Holdgate A, Pollock T. Systematic review of the relative efficay of non-steroidal anti-1nflamatory drugs and opiods in the treatment of acute renal colic. BMJ. 2004; 328:1401. https://doi.org/10.1136/bmj.38119.581991.55

29. Conk Z., Başbakkal Z., Yardımcı F. Çocuk Sağlığına Genel Bakış. İçinden; Conk Z., Başbakkal Z., Bal Yılmaz, H., Bolışık B (Eds). Pediatri Hemşireliği, Ankara, Akademisyen Tıp Kitabevi. 2013; 1-52.http://auzefkitap.istanbul.edu.tr/kitap/hemsirelik_ao/ hemsirelikbakimi4.pdf

30. Çavuşoğlu H. Çocuk Sağlığı Hemşireliği. Cilt 1. Genişletilmiş 11. Baskı Ankara, Sistem Ofset Basımevi. 2013; 1-31:51-70. https:// dergipark.org.tr/tr/pub/hunhemsire/issue/37313/454384

31. Wewers ME, Lowe NK. A critical review of visual analogue scales in the measurement Of clinical phenomena. Research in Nursing\&Health. 1990; 13:227-236. https://doi.org/10.1002/nur.4770130405

32. De Sio M, Autorino R, Quarto G, Mordente S, Giugliano F, Di Giacomo F, Neri F, et al. A new transportable shock-wave lithotripsy machine for managing urinary stones: a single-centre experience with a dual-focus lithotripter. BJU Int. 2007; 100. https:/doi. org/10.1111/j.1464-410x.2007.07039.x

33. Hasanpoura, M.,Tootoonchia, M., Aeinc, F. and Yadegarfara, G. (2006). The effects of two non-pharmacologic pain management methods for intramuscular injection pain in children. International Journal of Acute Pain Management. 8: 7-12. DOI: 10.1016/j. acpain.2005.11.001 